\title{
TEACHER LEADERSHIP FOR ORGANIZATIONAL CHANGE
}

\author{
Milda Damkuviené \\ Jūratè Valuckiené $\dot{e}^{* *}$ \\ Sigitas Balčiūnas ${ }^{* * *}$
}

Received: 29. 6. 2018

Original scientific paper

Accepted: 19. 3. 2019

UDC 371.1:005.3

DOI https://doi.org/10.30924/mjcmi.24.si.3

\begin{abstract}
The aim of this article is to test the teacher leadership initiated by teacher professional development abroad, as a factor of organisational change in a structural equation model. Structural equation modelling was employed to analyse survey data collected from 218 teachers who participated in professional development activities abroad under Erasmus + KAI in 32 Lithuanian schools. The model expresses the relationship between teacher leadership and organizational change, where teacher professional development abroad is treated as an initial (self-development) dimension of teacher leadership. Results revealed the positive and significant
\end{abstract}

\section{INTRODUCTION}

To meet the ever-changing economic, social, demographic and technological environment, there is a continuous need for schools to shape their culture, policy and practice to enhance student learning. Schools are seen as increasingly important players for the competitiveness of the countries as the education of its people relationship between teacher leadership and organizational change, where leadership is conceptualized as an ongoing relational process of selfdevelopment, dispersing ideas, involving others and gaining commitment. Findings of the study also depicted a positive and significant relationship of didactic competence (the dimension of self-development phase of leadership) with one of the dimensions of organizational change - learning in the classroom.

Keywords: teacher leadership, teacher professional development abroad, organizational change, structural equation model

is recognised to be an essential issue for the country's prosperity. School systems around the world strive to improve student achievement and promote the skills students need to participate effectively in national and global economies. To achieve this, many have been implementing schoolwide reforms focused on systemic school change (Karam, 2015). There is a growing

\footnotetext{
${ }^{*}$ Milda Damkuvienè, Šiauliai university, P.Višinskio str. 38, 76285 Šiauliai, Lihuania, Phone +370 68619902 , E-mail: m.damkuviene@gmail.com

** Jūratė Valuckiene, Šiauliai university, P.Višinskio str. 38, 76285 Šiauliai, Lihuania, Phone +370 65617532 , E-mail: j.valuckiene@gmail.com

**** Sigitas Balčiūnas, Šiauliai university, P.Višinskio str. 38, 76285 Šiauliai, Lihuania, Phone +370 69928361 , E-mail: balciunas@cr.su.lt
} 
understanding that teacher leadership embedded in various organisational contexts within school communities is as a critical element in the school improvement movement (Spillane et al., 2004; Kocolowski, 2010). The „leader-enriched” school community is continually learning from operational practice, cooperation, exchange of experiences. Teacher leaders, act for peer learning, promote institutional changes, create and encourage the shared learning culture. Discoveries with colleagues are taking place; professional development situations are enriching students' learning experiences and learning outcomes (Valuckienè et al., 2015). Such organisations benefit from better-informed decision making, shared ownership, and commitment to school goals (Matlach, 2015).

Today, school development studies have begun to focus on teacher leadership through strengthening of continuous professional development of teachers (Demir, 2015). Professional Development Models were initiated to target the self-development of teachers and principals using new approaches, enhancing themselves by implementing new information, sharing experiences with colleagues, and reflecting all of these into their school development and strategies (Dogan and Altun, 2018).

One of the initiatives that help to foster shared learning culture at schools and foster organisational change is ERASMUS+ programme KA1 for school education staff (teacher professional development abroad). Teacher professional development courses and other activities proposed by the ERASMUS + programme KA1 are seen as an opportunity to change teachers' professional and organizational practices at school. It is teachers, who develop their qualification abroad, who are expected to initiate leadership processes in their organization that in turn impacts changes at the organisational level.

The aim of this study is to test teacher leadership initiated by teacher professional development abroad, as a factor of organisational change in a structural equation model, where leadership is conceptualized as a process, which starts at the individual level (self-development) and through the dispersion of ideas, involvement of others and peer-commitment, which is transferred to the broader organisational contexts, i.e. facilitates organizational change.

The empirical data is taken from the research "Impact and sustainability of the ERASMUS + programme Key Action 1 (KA1) mobility projects for school education staff" which was initiated by the Education Exchanges Support Foundation (Lithuania) as a part of the ERASMUS+ programme Transnational Cooperation Activity funded by EU and performed by the authors of this article. The report is available online (Damkuvienè, Valuckienè and Balčiūnas, 2015).

From the year 2015, ERASMUS+ does not support individual applications for individual, teacher's qualification development. Only institutions with a clear vision of what impact the results of staff qualification improvement activities abroad have on the change of school's educational process were eligible for the programme grant (2014 call) (Damkuviené, Valuckienè and Balčiūnas, 2015). It is believed that the development of teacher professional competencies during ERASMUS+ KA1 mobility is an essential trigger for teacher leadership processes, causing the overall organizational change.

Limitations of the study are related to the data about attributes of teacher leadership and organizational change were 
collected with the help of self-reported questionnaires. Thus, the concepts of organizational change and teacher leadership have a notion of the personal perception. Also the results of the study might be affected by several potential sources of bias: “1) selective memory (remembering or not remembering experiences or events that occurred at some point in the past); 2) telescoping (recalling events that occurred at one time as if they occurred at another time); (3) attribution (the act of attributing positive events and outcomes to one's own situation but attributing negative events and outcomes to external forces); and, (4) exaggeration (the act of representing outcomes or embellishing events as more significant than is actually suggested from other data)" (Damkuviené, Valuckienè and Balčiūnas, 2015).

\section{CONCEPTUAL FRAMEWORK OF THE MODEL}

The conceptual framework for the model is guided by the prior research on leadership, where it is conceptualized as the continuous process of influence and change, which begins with the personal growth and then continuously expands to other wider contexts (group, organization, country etc.).

Further on the theoretical background of the conceptualization of teacher leadership for organizational change model is provided.

The process view on leadership is widely spread and acknowledged in the literature which describes leadership as a dynamic and ongoing process. As Hamilton (2012) states definitions of leadership may vary from "leader as coach" (Anderson, 1992; Anderson et al., 1998); to "leader as visionary or team leader" (Senge et al.,
1994; Flood, 1999); to leader as ,anyone who wants to help at this time" (Wheatley, 2006); to "leader as agent of change" (Eoyang \& Olson, 2001); and finally to "leader as a values-based organizational change agent".

The concept of teacher leadership has its roots in shared / distributed leadership (Gronn, 2000; Cheng and Szeto, 2016) and its nature is understood as ,fluid and emergent, rather than a fixed phenomenon" (Gronn, 2000, p. 324). This means that no one is assigned a specific role or leadership responsibility, rather, these roles emerge. Everyone in the organization has an equal opportunity to undertake leadership (Ulhoi and Müller, 2014). A distributed perspective of leadership highlights relationship and people's interactions (Harris, 2003; Harris and Spillane, 2008), collective and collaborative activities (Spillane and Camburn, 2006), team-level practices where behaviours are enacted by multiple individuals rather than persons in formal leadership roles (Carson et al., 2007). Leadership is described as "a dynamic, interactive influence process among individuals in groups for which the objective is to lead one another to the achievement of group or organizational goals or both" (Conger and Pearce, 2003 p. 1).

\subsection{Leadership dimension (1) - Self-development (development of didactic competence, intercultural competence, and openness to innovation)}

Leadership is anchored in a continuous commitment to self-development and personal growth. Leaders develop through a continuous process of self-study, education, training, and experience (Jago, 1982). This process is treated as the root of the egocentric stage of leadership development (Hamilton, 2012) and directly 
contributes to the broader process of leadership. According to the developmental theories, as humans develop, intelligence can increase in both quantity and quality and can be translated into an organizational context. Leadership lifecycle is expanding and deepening to the higher levels: managing and leading others, context and system (Hamilton, 2008, 2012). This means that "as the leaders mature through levels of complexity their spheres of influence grow with the contribution to many complex social systems, including families, groups, teams, organizations, communities, cities and nations at larger and larger scales" (Hamilton, 2010, p. 103).

Similarly, literature on educational effectiveness outlines a conceptual framework that can be described as an 'onionrings' model, going from the micro-level to the macro-level perspective - with individual teachers' personal characteristics (competencies, beliefs and attitudes) at the core, a second layer concerns teaching effectiveness in the classroom, a further layer is about teachers' cooperation in school contexts, and finally, the one that considers national policies and organizational features (including issues of autonomy, accountability, evaluation in education systems) as the outer layer (Clarke \& Hollingsworth, 2002).

Self-development is a competency development-based process and may occur in various ways, both formally and informally (Postholm, 2012). It is the process by which, alone and with others, teachers review, renew and extend their commitment as change agents to the moral purposes of teaching; and by which they acquire and develop the knowledge and skills essential to good professional practice (Day 1999). Teachers may develop their professional competencies through participation in various courses, in school when they reflect on their own teaching, in observation of and reflection on others', and while teaching in co-operation with colleagues.

In this study professional development abroad in the frame of ERASMUS+ KA1 projects is referred to as the self-development stage of leadership. On the basis of the ERASMUS+ Programme Guide (2015), where the expected teacher competence improvement areas are provided, and taking into consideration Gilis et al. (2008) notion about the most significantly considered typology of teacher competence in the literature (didactic competencies, professional attitude competencies and subject matter competencies), the development of didactic competence, intercultural competence, and openness to innovation were treated as constituent parts of the self-development construct.

It is believed, that this self-development stage gives teachers an injection of energy and inspiration for other leadership initiatives - dispersing the ideas taken from the mobility abroad to other colleagues, involvement and engagement of other colleagues to implement new teaching ideas at school.

\subsection{Leadership dimension (2) - Dispersing ideas}

Following the notion that leadership manifests itself through the connection between personal growth (self-development) and collective good, the act of dispersing the ideas, i.e. sharing their expertise, and best practices between and among colleagues (Andrews et al., 2002, Topolinski, 2014) is treated as the second dimension of leadership. It is a common understanding that change initiatives should be explained and communicated throughout the organization because it helps establish shared meanings. Teachers exhibit leadership in sharing the change vision, by sharing instructional 
resources with their colleagues (Gonzales and Lambert, 2014). Empirical studies have found that sharing leadership practices has important implications for discussion patterns and information-sharing in groups (Larson et al., 1998). When information is brought into the joint discussion and is possessed by all group members (shared information), the desired change is more likely to happen.

\subsection{Leadership dimension (3) - Involvement and engagement of others}

Leadership is captured in how people connect, inspire, and communicate with others (Bowman, 2015). Leading is inseparably related to influencing the direction of an intentional and purposive movement (Ulhoi and Muller, 2014). It may take various forms: mentoring, facilitating and modelling purposeful actions, aligning, mobilizing and inspiring others to act (Andrews et al., 2002, Topolinski, 2014, Anderson, 2008; York-Barr and Duke, 2004; Hanum et al., 2007; LeMay and Ellis, 2008). Following this, involvement and engagement of others in this study is treated as the third dimension of leadership.

\subsection{Leadership dimension (4) - Gaining commitment}

The process of leadership is an interactive, relational, and influence - based process defined not only by how the leader lead, but also how the followers follow. It is believed that there is a dynamic relationship of mutual influence between the leader and the follower. The relationship between leaders and followers has come to be seen as leadership behaviour. Leadership is seen as the process of not only persuading others to become committed to new ideas but also of the colleagues' eagerness to commit, lend their resources and energies to take the change initiative. The extent of the influence can be fluid and shift from the leader to the followers and back again. Leading and following are treated as the parts of the leadership process and must be understood in relation to each other. It means that in the leadership process, the followers have a vital role, because the way the influence of the leader is treated by the followers, reciprocally, determines the leadership process (Aleksic, 2016).

Following this, it is hypothesized that teacher leadership can be conceptualized as the process of Self-development (developing professional competencies: didactic competence, openness to innovation in education, intercultural competence), Dispersing ideas, Involving others and Gaining commitment.

\subsection{Organizational change}

Leadership is inseparably interconnected with change (Duignan and Bezzina, 2006). The organizational change, in brief, is an intentional effort made by an organization leader/leadership/manager to take the organization towards improvement. The organizational change is the set of different actions that result in shifting in directions and/or processes that affect the way in which organization worked before (Hage, 1999). Teacher leadership is an opportunity for teachers to develop themselves and affect change in their school (Harris and Muijs, 2003). In the ongoing process of leadership, it is expected that changes in individual practices lead to farther-reaching outcomes, i.e. organizational, system, and societal changes (Hanum et al., 2007; LeMay and Ellis, 2008). It is supposed that teachers implement change initiatives not only in their class, but actively make an effort to reach out to colleagues and to gain their commitment and energy to work on school improvements: the instructional 


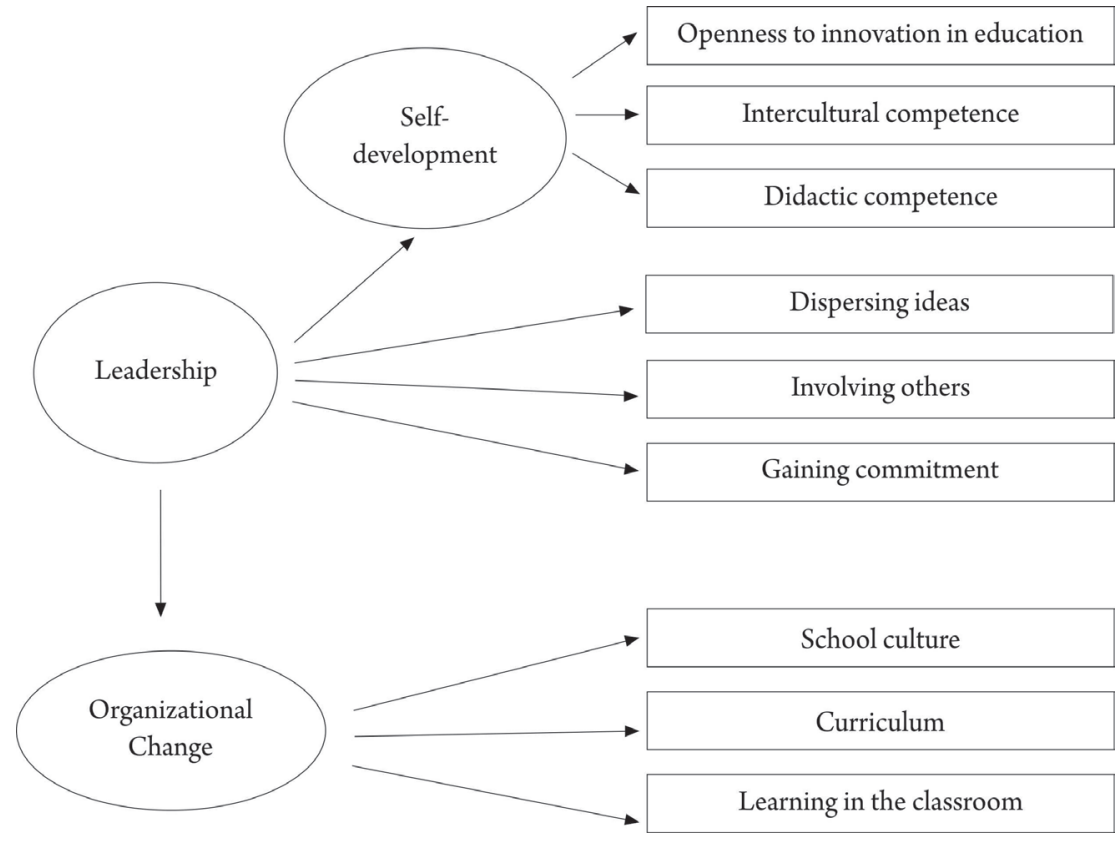

Figure 1. Conceptual framework of the teacher leadership for organizational change

knowledge and practice (Topolinski, 2014), student achievement (Harris and Spillane, 2008; Muijs and Harris, 2006; Timperley, 2005; Matlach, 2015). It is hypothesised that there is a relationship between leadership processes and the changes at the organizational level (school culture, curriculum, student learning in class).

The conceptual framework of the hypothesized relations between teacher leadership and organizational change is shown in the conceptual framework of the teacher leadership for the organizational change (Figure 1).

\section{RESEARCH METHODOLOGY}

\subsection{Data collection and research sample}

The data collection was performed through an online survey. An email was sent to invite teachers from 32 Lithuanian schools who had received a grant for ERASMUS + KA1 teacher mobility for the period from 2014 to 2016 to participate in the survey. The e-mail addressed the purpose of the questionnaire, the confidentiality statement, and the time needed to fill out the questionnaire. A link to a URL address was provided with instructions on how to begin and complete the questionnaire. In order to prevent multiple submissions from one person, respondents had to $\log$ in with their email address and the password which was provided in the email. A total of 289 questionnaires were distributed to teachers who had participated in the ERASMUS+ KA1 professional development activities abroad during the mentioned period. 223 questionnaires (response rate $75.4 \%$ ) were received, of which 218 responses were used for data analysis. Detailed characteristics of the research sample are presented in Table 1. 
Management, Vol. 24, 2019, Special Issue, pp. 37-53 M. Damkuvienė, J. Valuckienė, S. Balčiūnas: TEACHER LEADERSHIP FOR ORGANIZATIONAL...

Table 1. Profile of respondents ( $N=218,32$ schools)

\begin{tabular}{|c|c|c|c|}
\hline Characteristics & Category & Frequency & Percentage \\
\hline \multirow[t]{4}{*}{ Work experience } & Less than 5 years & 13 & 6.0 \\
\hline & From 5 to 15 years & 59 & 27.1 \\
\hline & From 16 to 25 years & 62 & 28.0 \\
\hline & More than 25 years & 84 & 38.5 \\
\hline \multirow{3}{*}{$\begin{array}{l}\text { School size (number } \\
\text { of students) }\end{array}$} & Less than 300 & 45 & 20.6 \\
\hline & From 301 to 500 & 39 & 17.9 \\
\hline & More than 500 & 134 & 61.5 \\
\hline \multirow[t]{4}{*}{ School location } & A village, hamlet, or rural area (fewer than 3,000 people) & 47 & 21.6 \\
\hline & A small town $(3,000$ to about 15,000 people $)$ & 37 & 17.0 \\
\hline & A town $(15,000$ to about 100,000 people $)$ & 24 & 11.0 \\
\hline & A city $(100,000$ to about $1,000,000$ people) & 110 & 50.5 \\
\hline
\end{tabular}

Teachers from different types of school locations, schools of different sizes attended professional development activities abroad, but more than half of them were from larger cities. However, comparing the characteristics of the sample with the original national population of teachers according to the work experience, it was found out that teachers in the research sample were with somewhat less work experience $\left(\chi^{2}(1)=11,1, p=0.001\right)$ than the national population. 33.1 percent of teachers in the research sample had been teaching not more than 15 years. Meanwhile, the national percentage of such teachers is 23.1 .

\subsection{Questionnaire development}

Following the theoretical conceptualization of leadership as the process of selfdevelopment (development of professional competencies), dispersion of ideas, involvement of others and gaining commitment and following the hypothesized relation between teacher leadership and organizational change, nine scales were developed to collect information about the attributes of teacher leadership and organizational change.
Items, indicating four leadership dimensions: (1) Self-development (with its components: Openness to innovation in education, Intercultural competence, Didactic competence), (2) Dispersing ideas, (3) Involving others, (4) Gaining commitment were drawn. Sample items regarding teacher Selfdevelopment follow: "Obtained stimulus to change my teaching style", "Deepened my understanding of other cultures", "Acquired new teaching methods". A sample item for Dispersing ideas is: "Made a presentation at the teachers' conference", for Involving others: "Build teams to implement new ideas", for Gaining commitment is "School's colleagues support new ideas taken from Erasmus+ mobility".

Organizational change (with its dimensions: School culture, Curriculum, Learning in the classroom) included statements such as: "Tolerance and openness has been increasing" (School culture dimension), "Content of the curricula has been changing" (Curriculum dimension), "Pupils in class have been working more creatively and actively" (Learning in the classroom dimension). Participant responses were recorded on a 5-point Likert scale 
ranging from „1“ — strongly disagree and „5“- strongly agree.

All variables were examined for the accuracy of data entry, missing values, fit between their distributions and assumptions of multivariate analysis (Čekanavičius, Murauskas, 2003). All assumptions are fulfilled, but not all variables were deemed strictly normally distributed.

\subsection{Scale development}

The principal component analysis (PCA) using IBM SPSS 21 (loadings of 0.5 or higher (Hair et al., 2010)) was used for scale construction. The results showed nine significant factors. Using Kaiser criterion in each case one factor was identified, explaining from $42 \%$ to $74 \%$ of the variance (see $\%$ of Variance in Table 2). Items with factor loadings of less than 0.5 , and therefore not making a good contribution to their predicted constructs, were deleted from the scales. The ratio of the first and second eigenvalues for all the scales was from 2.4 to 4.5 (see $\lambda_{1} /$ $\lambda 2$ in Table 2). Accordingly, items appear to consist of one unidimensional construct.

Cronbach's alpha was used to examine reliability. Reliability coefficient Cronbach $\alpha \geq 0.70$ is good, whereas 0.70 $\geq \alpha \geq 0.60$ is seen as acceptable (Hair et al. 2006; Čekanavičius, Murauskas, 2003). Reliability of all the scales was in a good (six scales) to acceptable (two scales) range (see Table 2). Dispersing ideas scale was created as a formative construct, as it composes from different information sharing activities and initiatives performed by teachers inside and outside the school. Teachers choose the information channels and target groups that are most acceptable and appropriate. In the formative construct model cause indicators could be intercorrelated positively, negatively or have zero correlation. So, internal consistency is not required in formative models (Hoyle, 2012, p.119, 120).

Table 2. Results of Principal Component Analysis (PCA)

\begin{tabular}{lcccc}
\hline \multicolumn{1}{c}{ Scale } & $\begin{array}{c}\mathrm{N} \text { of } \\
\text { items }\end{array}$ & $\lambda_{1} / \lambda_{2}$ & $\%$ of variance & Cronbach alpha \\
\hline $\begin{array}{l}\text { Openness to innovation in } \\
\text { education }\end{array}$ & 2 & 2.9 & 74.5 & 0.66 \\
$\begin{array}{l}\text { Intercultural competence } \\
\text { Didactic competence }\end{array}$ & 4 & 2.5 & 49.8 & 0.67 \\
Dispersing ideas & 4 & 2.7 & 51.4 & 0.68 \\
Involving others & 8 & - & - & - \\
Gaining commitment & 5 & 2.4 & 42.0 & 0.65 \\
School culture & 2 & 2.6 & 71.9 & 0.61 \\
Curriculum & 3 & 2.9 & 63.5 & 0.71 \\
Learning in the classroom & 3 & 4.2 & 70.5 & 0.79 \\
\hline
\end{tabular}

Note. All variables reported in this study, excluding Dispersing ideas, and Involving others are scored on 1-5 Likert-like scales ranging from completely disagree (1) to completely agree (5). The items for the scale Dispersing ideas is dichotomous. 
To measure the internal consistency and reliability of the two latent variables (teacher leadership and organisational change) the composite reliability measures (CR) and Cronbach's alpha were used. According to Hair et al. (2010), the acceptable value of $\mathrm{CR}$ is 0.7 and above. The acceptable value for Cronbach's alpha is $>0.6$ (Čekanavičius, Murauskas, 2003).

Convergent validity test is aimed at verifying whether the components are sufficiently correlated with the respective latent variable. Convergent validity of the teacher leadership was presented in the form of average variance extracted (AVE). The values of average variance which extracted more than 0.7 is considered very good, whereas, the level of 0.5 and above is acceptable (Hair et al., 2010).

\subsection{Methods}

The interdependence among all variables was analyzed using the Spearman correlation coefficient since not all variables were considered normally distributed. Z-test was used to compare the correlations. It allowed us to estimate, which teacher leadership variables have a stronger impact on organizational changes.

Structural Equation Modeling (SEM) techniques, which allow evaluating how closely a theoretical model fits an actual data set, were used to test the hypothesized model of teacher Leadership impact to Organizational change (IBM SPSS Amos Version 22). The variance-covariance matrix was analyzed using the maximumlikelihood estimation and using multiple indices of model fit including the ChiSquare statistic $\left(\chi^{2}\right)$, the Comparative fit index (CFI), the Tucker-Lewis index (TLI), Normed-fit index (NFI), the Standardized root mean square residual (SRMR), and the Root mean square error of approximation
(RMSEA). A value of CFI $\geq 0.95, T L I \geq 0.95$, $\mathrm{NFI} \geq 0.95$ is presently recognized as an indicator of a good model fit. A cut-off value for RMSEA close to the upper limit of 0.08 is recommended (Čekanavičius, Murauskas, 2009). Values lower than 0.08 for the SRMR indicate well-fitting models (Hooper et al., 2008).

\section{RESULTS AND DISCUSSION}

A Spearman's correlation coefficient was computed to assess the relationship among the variables.

Descriptive statistics and intercorrelations of all measured variables are presented in Table 3.

As expected, the correlation of all leadership dimensions is positive and statistically significant. The items reflecting Self-development dimension of teacher leadership, reflecting professional development abroad outcomes (Openness to innovation in education, Intercultural competence, Didactic competence) possessed a significant medium-strength inter-correlation $(\mathrm{p}<0.01)$. Both Dispersing ideas and Involving others are related to Openness to innovation in education, while the correlation of Involving others is stronger $(\mathrm{z}=1.825, \mathrm{p}=0.034)$.

Dispersing ideas has a stronger relationship with Involving others, however, it has a weaker link with Gaining commitment $(\mathrm{z}=4.47 \mathrm{p}<.001)$. This means that teachers who are active in dispersing ideas put much effort to involve others, but the commitment of colleagues (earning support and involvement) is not so strongly related to the efforts to disperse ideas.

The evaluation of relationships of separate Leadership dimensions with Organizational change shows that 
Table 3. Intercorrelations of the constructs (Mean, standard deviation (SD) and Spearman's correlation ( $r s), N=218$ )

\begin{tabular}{llccccccccc}
\hline \multicolumn{1}{c}{ Scale/construct } & 1 & 2 & 3 & 4 & 5 & 7 & 6 & 7 & 8 \\
\hline 1 & Openness to innovation in education & 1,00 & & & & & & & & \\
2 & Intercultural competence & 0.56 & 1.00 & & & & & & & \\
3 & Didactic competence & 0.51 & 0.59 & 1.00 & & & & & & \\
4 & Dispersing ideas & 0.36 & 0.39 & 0.37 & 1.00 & & & & & \\
5 & Involving others & 0.47 & 0.55 & 0.46 & 0.50 & 1.00 & & & & \\
6 & Gaining commitment & 0.40 & 0.47 & 0.50 & 0.29 & 0.46 & 1.00 & & & \\
7 & School culture & 0.45 & 0.49 & 0.39 & 0.22 & 0.52 & 0.54 & 1.00 & & \\
8 & Curriculum & 0.37 & 0.37 & 0.43 & 0.18 & 0.35 & 0.43 & 0.59 & 1.00 & \\
9 & Learning in the classroom & 0.43 & 0.0 & 0.56 & 0.27 & 0.40 & 0.53 & 0.58 & 0.59 & 1.00 \\
\hline & Descriptive statistics & & & & & & & & & \\
\hline & Mean & 4.29 & 4.34 & 3.78 & 0.60 & 4.36 & 3.95 & 4.06 & 3.91 & 3.89 \\
& SD & 0.60 & 0.50 & 0.63 & 0.2 & 0.29 & 0.55 & 0.53 & 0.59 & 0.56 \\
\hline
\end{tabular}

Note. Items (excluding Dispersing ideas scale) were rated on a 5-point Likert-type scale. Items of Dispersing ideas scale is dichotomous. $r$ s over 0.17 is significant at $p<0.01$.

Development of Didactic competence abroad is more related to the changes in the classroom (Learning in the classroom) than to the changes at school level (School culture) $(\mathrm{z}=1.79, \mathrm{p}=0.04)$. Teachers who report a higher level of Intercultural competence development, report higher School culture change rate compared to the changes in Curriculum ( $\mathrm{z}=2.21, \mathrm{p}=0.014)$ or Learning in the classroom $(\mathrm{z}=1.654, \mathrm{p}=0.049)$.

This could be explained through the lens of competency levels (attitudinal and professional) and organization as a complex system level (observed behaviours, structures and organizational culture). Intercultural competence development reflects knowledge, attitude and skill development necessary to understand different perspectives derived from cultural differences, such as different ethical standards, languages, and perspectives. Didactic competence is more related to the development of specific professional competencies in the subject area, teaching techniques, students assessment, class management etc. It makes sense that the self-development in the area of didactic competence, in turn, gives higher effect to the changes in the class level and the development of intercultural competence has a higher impact on the changes at the school level.

\subsection{Model}

The conceptualization of teacher leadership and its impact on organizational change is based on extensive studies of leadership and organisational change, whereas the operationalisation we employ in this study is aimed to test the hypothesized conceptualization of teacher leadership and its relation to organizational change, when teacher professional development abroad (ERASMUS+ KA 1 staff mobility) is treated as the self-development dimension of leadership.

The hypothesized structure of the confirmed measurement model is presented in Figure 2. 


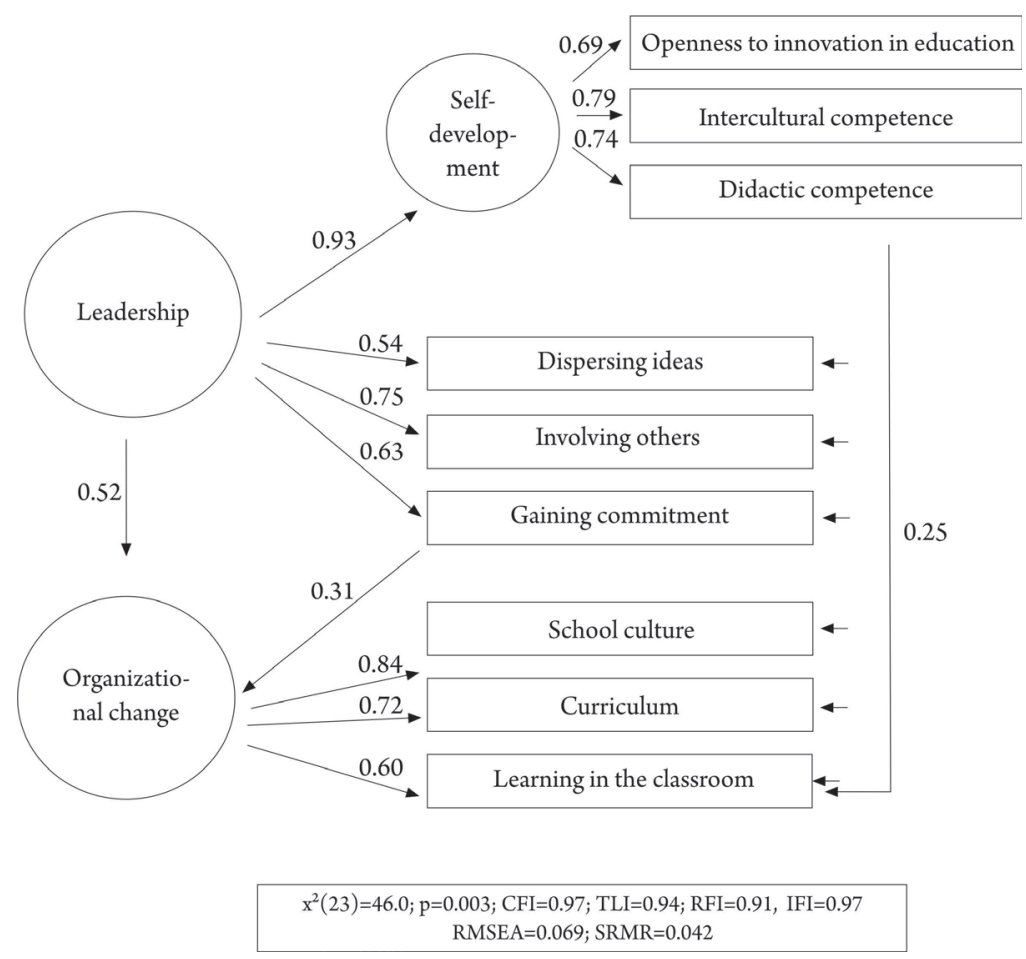

Figure 2 Teacher leadership for organizational change model

In the measurement model (CFA), the latent variable teacher leadership is indicated by 4 categorical variables: Selfdevelopment, Dispersing ideas, Involving others, Gaining commitment.

The results indicated an acceptable model fit by most indices $\left(\chi^{2}(16)=23.7 \backslash\right.$, $\mathrm{p}=0.097 \mathrm{CFI}=0.99 ; \mathrm{TLI}=0.98 ; \mathrm{RFI}=0.95$; IFI $=0.99 ; \quad$ RMSEA $=0.034, \quad$ SRMR $=0.029$. All factor loadings are above recommended threshold level 0.50 . The highest factor load is observed in the Self-development dimension $(\lambda=0.91)$, the least - Dispersing ideas $(\lambda=0.57)$.

The Average Variance Extracted (AVE), which measures the level of variance captured by the construct versus the level due to measurement error is acceptable - 0.61. Internal consistency reliability coefficients were sufficient: Composite reliability 0.86 , Cronbach alpha -0.74 . Based on the above-mentioned criteria, it can be concluded that the measurement model of Teacher leadership construct has satisfied the criteria of appropriateness. It means that teacher leadership can be conceptualized as a latent construct composed of the Selfdevelopment, Dispersing ideas, Involving others, Gaining commitment.

The latent variable organizational change reflects the changes in School culture, Curriculum and Learning in the classroom. The results indicated an acceptable CFA model fit by most indices $\left(\chi^{2}\right.$ $(21)=31.6, p=0.063 ; \mathrm{CFI}=0.99 ; \mathrm{TLI}=0.98$; RFI $=0.93 ; \quad$ IFI $=0.99 ; \quad$ RMSEA $=0.049$, $\mathrm{SRMR}=0.034)$. Internal consistency reliability coefficients were sufficient: Composite reliability - 0.88 , Cronbach 
alpha -0.81 . All factor loadings are aboverecommended threshold level 0.50 . The factor School culture indicates the highest factor load $(\lambda=0.87)$, while Learning in the classroom had the lowest factor load $(\lambda=0.82)$.

The Structural Equation Modelling (SEM) was performed on these variables, and the model that expressed the positive correlations among the variables was constructed. SEM procedures allow determining the extent to which these hypothesized structure specifications are consistent with the data.

The results indicated an acceptable model fit by most indices $\left(\chi^{2}(30)=48.4\right.$, $\mathrm{p}=0.003 ; \mathrm{CFI}=0.97 ; \mathrm{TLI}=0.94 ; \mathrm{RFI}=0.91$; $\mathrm{IFI}=0.97 ; \mathrm{RMSEA}=0.069$, SRMR=0.042). All factor loadings are above-recommended threshold level 0.50. The highest factor load is observed in the Self-development component $(\lambda=0.93)$, the lowest - Dispersing ideas $(\lambda=0.54)$ The standardized parameters of the model evidenced the positive influence of teacher Leadership on Organizational change $(\beta=0.52, p<0.001)$. It allowed us to conclude that the observed data match the relationships, specified in a hypothesized model.

Modification indices suggested direct paths added from Gaining commitment to organizational change $(\beta=0.31, p<0.001)$, and from Didactic competence to Learning in the classroom $(\beta=0.25, p<0.001)$. These results indicate that overall organizational change is affected by teacher leadership $(\beta=0.52, \quad p<0.001)$, supported by direct impact of Gaining commitment $(\beta=0.31$, $p<0.001$ ), and the relationship between Didactic competence and Learning in the classroom $(\beta=0.25, p<0.001)$.

In order to assess the significance of the model, a Monte-Carlo (bootstrapping) approximation was used by constructing a bias-corrected percentile method (200 samples; confidence interval of 90). It demonstrated that leadership is positively related to organizational change $(\beta=0.52$, $p=0.004)$ through the mediating construct Gaining commitment $(\beta=0.31, p=0.01)$, and through the positive association of Didactic competence with Learning in the classroom.

These results say that the development of didactic competence (as the self-development phase of teacher leadership) predicts higher results of learning in the classroom (as Organizational change dimension). Teachers who declared that their didactic competence had increased after professional development abroad more often recognized that Students in the class have been working more creatively and actively; Students learning motivation has been increasing; Students' learning results have been improving.

Also, our research shows the importance of gaining commitment (School's colleagues support and participation) in organizational change. These results support the conceptualizations of leadership that involve both leaders and followers, saying that leadership causing organizational change implies followership (Alvesson and Blom, 2015, DeRue and Ashford, 2010).

\section{CONCLUSIONS}

The study supported the idea that teachers' professional development abroad in the frame of Erasmus + staff mobility can be treated as self-development stage of teacher leadership. Together with other dimensions it composes a meaningful leadership construct.

Leadership can be conceptualized as an ongoing relational process of 
self-development, dispersing ideas, involving others and gaining commitment, supporting the idea that it is not only a continuous process of being pro-active, leading but also as the process of followership (earning support and involvement of colleagues).

The model confirms that leadership triggered by teachers' professional development abroad influences organizational change suggesting further support towards enhancing collective teacher learning as a

\section{References}

1. Aleksic, V. S. (2016). Followers in the organizational leadership process: from attribution to shared leadership. Economic Horizons, 18(2), pp. 135-148

2. Alvesson, M. Blom, M. (2015). Less Followership, Less Leadership? An Inquiry Into the Basic But Seemingly Forgotten Downsides of Leadership. M@n@gement,18(3),pp.266-282.

3. Anderson, T. D. (2008). Transformational teacher leadership in rural schools. The Rural Educator, 29(3), pp. 8-17.

4. Anderson, T. D. (1992). Transforming Leadership: New Skills for an Extraordinary Future, Amherst, Mass.: HRD Press, Inc.

5. Anderson, T. D., Ford, R., Hamilton, M. (1998). Transforming Leadership: Equipping Yourself and Coaching Others to Build a Leadership Organization, Boca Raton, St. Lucie Press.

6. Andrews, D., Crowther, F., Hann, L., McMaster, J. (2002). Teachers as leaders: RE-imaging the profession, The Practising Administrator, (1).

7. Bowman, R. F. (2015). Teachers as Leaders: A Commitment to SelfDevelopment. Academic Exchange mechanism for activating teacher leadership for school change.

If more teachers are active in their development in the sphere of didactic competencies, changes in the classroom level (pupils learning) will occur more likely. It means that the development of didactic competence as a dimension of self-development component of leadership has a strong impact on the changes in the classroom.

Quarterly, 19(1). On-line: http://rapidintellect.com/AEQweb/5522z4.pdf 2017-03-07

8. Carson, J. B., Tesluk, P. E., Marrone, J. A. (2007). Shared leadership in teams: An investigation of antecedent conditions and performance. Academy of Management Journal, 50(5), pp. 1217-1234.

9. Čekanavičius, V., Murauskas, G. (2002). Statistika ir jos taikymai II. Vilnius: TEV.

10. Čekanavičius, V., Murauskas, G. (2002). Statistika ir jos taikymai III. Vilnius: TEV.

11. Cheng, A. Y. N., Szeto, E. (2016). Teacher leadership development and principal facilitation: Novice teachers' perspectives. Teaching and Teacher Education, 58 pp. 140-148

12. Clarke, D. J. Hollingsworth, H. (2002). Elaborating a model of teacher professional growth. Teaching and Teacher Education, 18, pp. 947-967.

13. Conger, J. A., Pearce, C. L. (2003). A landscape of opportunities: Future research on shared leadership. In C. L. Pearce \& J. A. Conger (Eds.), Shared leadership: Reframing the hows and whys of leadership (pp. 285-303). Thousand Oaks, CA: Sage Publishing Company. 
14. Day, C. (1999). Developing Teachers: the challenges of lifelong learning. London: Falmer Press.

15. Day, C., Sammons, P., Hopkins, D., Leithwood, K., Kington, A. (2008). Research into the Impact of School Leadership on Pupil Outcomes: Policy and Research Contexts. School Leadership and Management, 28 (1), pp. 5-25.

16. Demir, K. (2015). The Effect of Organizational Trust on the Culture of Teacher Leadership in Primary Schools. Educational Sciences: Theory \& Practice, June,15(3), pp. 621-634.

17. DeRue S., Ashford, S. (2010). Who will lead and who will follow? A social process of leadership identity constructions in organizations. Academy of Management Review, 35(4), pp. 627-647.

18. Doğan, Z. Y., Altun, S. (2018). The Effect of the Research Lesson Study (RLS) Model on Teachers' Professional Development, International Online Journal of Educational Sciences, 10(3), pp. 244-258.

19. Drath, W. H., McCauley, C. D., Palus, C. J., Van Velsor, E., O'Connor, P. M. G., McGuire, J. B. (2008). Direction, alignment, commitment: Toward a more integrative ontology of leadership. The Leadership Quarterly, 19, pp. 635-653.

20. Duignan, P., Bezzina, M. (2006). Building a Capacity for shared leadership in school's teachers as leaders of educational change, Educational Leadership Conference University of Wollongong February, 2006. Online: https://www.uow.edu.au/content/ groups/public/@web/@educ/documents/doc/uow037796.pdf

21. Eoyang, G., Olson, E. (2001). Facilitating Organization
Change: Lessons from Complexity Science. San Francisco: Jossey-Bass Pfeiffer.

22. ERASMUS+ Programme Guide (2015). Version 2 (2015): 23/10/2014. On-line: http:// ec.europa.eu/programmes/erasmusplus/sites/erasmusplus/files/files/ resources/2015-guide-v-2_en.pdf

23. Flood, R. (1999). Rethinking the Fifth Discipline: Learning Within the Unknowable. London: Routledge.

24. Gilis, A., Clement, M., Laga, L. Pauwels, P. (2008). Establishing a competence profile for the role of student-centered teachers in higher education in Belgium. Research in Higher Education, 49, pp. 531-554. On-line: http://dx.doi.org/10.1007/ s11162-008-9086-7

25. Gonzales, S., Lambert, L. (2014). Teacher leadership in professional development schools: emerging conceptions, identities, and practices, Journal of School Leadership, 11(1), pp. 6-24.

26. Greenwood, R., Hinings, B. (1996). Understanding radical organisational change: Bringing together the old and the new institutionalism. Academy of Management Review, 21(4), pp.1022-1054.

27. Grondin, J. (2011). Gadamer's experience and theory of education: Learning that the other may be right. In P. Fairfield, (Ed.), Education, dialogue and hermeneutics: 5-20. London: Continuum.

28. Gronn, P. (2000). Distributed properties: A new architecture for leadership. Educational Management \& Administration, 28(3), pp. 317-338.

29. Hage, J. (1999). Organizational innovation and organizational change, Annual Review of Sociology, 25, pp. 597-622. 
30. Hair, J., F., Black, W., C., Babin, B., J., Anderson, R., E. (2010). Multivariate data analysis. Pearson Education: Upper Saddle River, N. J.

31. Hamilton, M. (2008). Leadership Development: Accelerating the Development of Post-Convential Leaders. Sense in the City, October. On-line: http://integralcity.com/Ezine \%20Files/Ezine \%20 oct $072008 \% 20$ iss $22 . \mathrm{html}$

32. Hamilton, M. (2010). Integral City: Meshworking Evolutionary Intelligences for the Human Hive and Eco-Region Resilience. On-line: http:// integralcity.com/

33. Hamilton, M. (2012). Leadership to the Power of 8: Leading Self, Others, Organization, System and SupraSystem Integral leadership review, Online: http://integralleadershipreview. com/7686-leadership-to-the-power-of8-leading-self-others-organization-system-and-supra-system/

34. Hannum, K. M., Martineau, J., W., Reinelt, C. (eds.) (2007). The Handbook of Leadership Development Evaluation, San Francisco, CA: Jossey-Bass.

35. Harris, A. (2003). Teacher leadership as distributed leadership: heresy, fantasy or possibility? School Leadership \& Management, 23(3), pp. 313-324.

36. Harris, A., Muijs, D. (2003). Teacher leadership: principles and practice. London, UK: National College for School Leadership. On-line: www.nut. org.uk

37. Harris, A., Spillane, J. (2008). Distributed leadership through the look glass. British Educational Leadership, Management \& Administration Society, 22(1), pp. 31-34.

38. Herscovitch, L., Meyer, J. P. (2002) Commitment to organizational change: extension of a three component model, Journal of Applied Psychology, 87, pp. 474-487.

39. Hooper, D., Coughlan, J., Mullen, M. (2008). Evaluating model fit: a synthesis of the structural equation modelling literature. In 7th European Conference on research methodology for business and management studies, pp. 195-200.

40. Hoyle, R. H. ed., 2012. Handbook of structural equation modelling. Guilford Press.

41. Damkuvienè, M., Valuckienè, J., Balčiūnas, S. (2015). Impact and sustainability of the Erasmus + Programme Key Action 1 mobility projects for school education staff. Research report. On-line: http://erasmus-plius.lt/uploads/files/2015-12-18inational-report.pdf

42. Jago, A.G. (1982). Leadership: Perspectives in theory and research. Management Science, 28(3), pp. 315-336.

43. Karam., R. (2015). Implementing Education Reforms to Enhance School Performance, November 13, 2015 on-line: http://www.rand.org/ blog/2015/11/implementing-educationreforms-to-enhance-school-performance.html 2017-03-14.

44. Kocolowski, M. D. (2010). Shared leadership: Is it time for a change? Emerging Leadership Journeys, 3(1), pp. 22-32.

45. Kotter, J. P., Heskett, J. L. (1992). Corporate Culture and Performance. Free Press, New York.

46. Larson, J. R., Foster-Fishman, P. G., Franz, T. M. (1998). Leadership style and the discussion of shared and unshared information in decision-making groups. Personality and Social Psychology Bulletin, 24(5), pp. 482-495. 
47. Leithwood, K., Day, C. (2008). The Impact of School Leadership on Pupil Outcomes. School Leadership \& Management 28(1), pp. 1-4.

48. LeMay, N., Ellis, A. (2008). Leadership Can Be Learned, But How Is It Measured? Management Sciences for Health MSH Occasional paper, 8, pp. 1-28.

49. Marcinkus M., W. (2012). Reverse mentoring at work: Fostering crossgenerational learning and developing millennial leaders. Human Resource Management, 51, pp. 549-573.

50. Matlach, L. Increasing Teacher Leadership. (2015). Center on great teachers \& leaders at American institutes for research, pp. 1-12. On- line: http://www.gtlcenter.org/sites/default/ files/Snapshot_Teacher_Leadership. PDF

51. Muijs, D., Harris, A. (2006). Teacher led school improvement: Teacher leadership in the UK. Teaching and Teacher Education, 22(8), pp. 961-972.

52. Neves, P. (2009). Readiness for change: Contributions for employee's level of individual change and turnover intentions. Journal of Change Management, 9(2), pp. 215-231.

53. Postholm, M. B. (2012) “Teachers' Professional Development: A Theoretical Review". Educational Research 54 (4), pp. 405-429.

54. Senge, P., Kleiner, A., Roberts, C., Ross, R., \& Smith, B. (1994). The Fifth Discipline Fieldbook: Strategies and Tools for Building a Learning Organization, New York: Currency Doubleday.

55. Spillane, J. P., Camburn, E. (2006). The practice of leading and managing: The distribution of responsibility for leadership and management in the schoolhouse. In Paper presented at the annual conference of the American Education Research Association 2006, San Francisco, U.S.A.

56. Spillane, J.P., Halverson, R. \& Diamond, J.B. (2004). Towards a theory of leadership practice: a distributed perspective, Journal of Curriculum Studies, 36(1), pp. 3-34.

57. Timperley, H. S. (2005). Distributed leadership: developing theory from practice. Journal of Curriculum Studies, 37(4), pp. 1-26.

58. Topolinski, Ch. C., (2014). The Influence of Teacher Leadership and Professional Learning on Teachers' Knowledge and Change of Instructional Practices in Low Performing Schools. Dissertations. Paper, p. 265. Online: http://scholarworks.wmich.edu/cgi/viewcontent.cgi? article $=1266 \&$ context $=$ dissertations

59. Ulhoi, J. P., Müller, S. (2014). mapping the landscape of shared leadership: a review and synthesis International Journal of Leadership Studies, 8(2), pp. 66-88

60. Valuckienè, J. Balčiūnas, S. Katiliūtè, E., Simonaitienè, B. Stanikūnienè, B. Lyderystè mokymuisi: teorija ir praktika mokyklos kaitai. Online: https:// www.sac.smm.1t/wp-content/uploads/2016/01/Lyderyste-mokymuisi teorija-ir-praktika-mokyklos-kaitai.pdf

61. Wheatley, M. (2006). Leadership and the New Science: Learning about Organization from an Orderly Universe. San Francisco: Berrett-Koehler.

62. York-Barr, J., Duke, K. (2004). What do we know about teacher leadership? findings from two decades of scholarship. Review of Educational Research, 74(3), pp. 255-316. 


\section{NASTAVNIČKO VOĐENJE ZA ORGANIZACIJSKE PROMJENE}

Sažetak

Cilj ovog rada je ispitati ulogu nastavničkog vođenja, nastalog uslijed profesionalnog razvoja u inozemstvu, kao čimbenika organizacijskih promjena, korištenjem modela strukturnih jednadžbi. Modeliranje strukturnih jednadžbi je korišteno za analizu anketnih podataka, prikupljenih od 218 nastavnika, koji su sudjelovali u aktivnostima profesionalnog usavršavanja u inozemstvu, $u$ okviru programa Erasmus plus KA1 (Key Activity 1), u 32 litvanske škole. Model pokazuje postojanje odnosa između nastavničkog vođenja i organizacijskih promjena, pri čemu se profesionalno usavršavanje nastavnika u inozemstvu tretiralo kao inicijalna dimenzija nastavničkog vođenja.
Rezultati istraživanja pokazuju pozitivnu $i$ značajnu vezu između nastavničkog vođenja i organizacijskih promjena, pri čemu se vođenje konceptualizira kao trajni relacijski proces samostalnog profesionalnog razvoja, širenja ideja, uključivanja ostalih $i$ povećanja vlastite predanosti. Rezultati studije, također, ukazuju na pozitivnu $i$ značajnu vezu didaktičkih kompetencija (unutar dimenzije samostalnog razvoja nastavničkog vođenja) s jednom od dimenzija organizacijskih promjena, $i$ to s učenjem u razredu.

Ključne riječi: nastavničko vođenje, profesionalno usavršavanje nastavnika u inozemstvu, organizacijske promjene, sustav strukturnih jednadžbi 